\title{
Some Immunologic Considerations in Focal Scleroderma and Progressive Systemic Sclerosis in Children
}

\author{
-VIRGIL HANSON, ${ }^{(27)}$ HELEN K. KORNREICH, AND ELIZABETH DREXLER \\ Department of Pediatrics, University of Southern California School of Medicine, and \\ The Children's Hospital of Los Angeles, Division of Rheumatology and Rehabilitation, \\ Los Angeles, California, USA \\ GERALD D. JOHNSON \\ Rheumatism Research Unit, Canadian Red Cross Memorial Hospital, Taplow, Maidenhead, Berks, England
} GEOFFREY A. MACPHERSON

United States Naval Hospital, San Diego, California, USA

Extract

Immunoglobulins (Ig) $\mathbf{G}, \mathbf{M}$, and $\mathbf{A}$ were significantly elevated in children with focal scleroderma (FS) and progressive systemic scleroderma (PSS), and were significantly higher in those patients who had rheumatoid factor or antinuclear antibodies than in those who did not. Antinuclear antibodies were found in 13 of 23 children with FS and in 5 of 6 children with PSS. Significantly increased binding of antibody to native DNA was detected by radioimmunoassay in 5 of 16 children with FS and in 0 of 6 children with PSS. Persistence of DNA antibody for 6-12 months was demonstrated in two patients with FS and the DNA binding activity correlated with the serum levels of IgG and IgM. The persistence of the high levels of immunoglobulins and autoantibodies are strong evidence of an antigen involved in scleroderma pathogenesis. A case is presented in which antibodies to a specific exogenous antigen (Epstein-Barr virus antigen) were associated with advancing focal scleroderma lesions.

\section{Speculation}

The fibrosis of scleroderma is probably initiated by an inflammatory process and is accompanied by significantly increased immune activity which indicates an antigen intimately associated with the disease process. The primary antigen is probably exogenous in origin but may give rise to sclerodermatous changes through secondary effects on local tissue antigens.

The hallmark of scleroderma is an increase of fibrous tissue, particularly of collagen fibers in skin and other affected organs; however, satisfactory theory of pathogenesis has been difficult to develop. Consideration has been given to abnormalities of collagen metabolism, ground substance, and vascular structure and function, but the possible role of immune mechanisms has been thought to be less significant (23). Repeated findings of antinuclear antibody and anti- $\gamma$ globulins in children with both FS and PSS suggested the hypothesis that the immune system is significantly involved in this disease.

\section{MATERIALS AND METHODS}

Twenty-three children with FS and 6 with PSS were studied and the findings were compared with those in 23 normal children of the same age and sex distribution. The FS group was composed of 15 males and 8 females with an age range at onset of 1-14 years. The six children with PSS were three males and three females ages 3-12 years at onset. Diagnosis was based on typical clinical and biopsy findings as described previously (15). Serum was obtained from each patient at the first examination and annually or more frequently thereafter. All sera were frozen immediately and stored at $-20^{\circ}$ until used.

The immunoglobulins and third component of complement were measured by radial immunodiffusion as described by Allansmith et al. (1). All determinations were run in duplicate. The accuracy of measurement of diffusion rings in a sample of 10 determinations was confirmed by measuring the diffusion rings under a low power objective utilizing the Vernier scale of the microscope stage.

Antinuclear antibodies (ANA) were detected by immunofluorescence using human leucocytes, unfixed fresh-frozen rat liver sections, and nucleohistone spots as substrates $(9,10$, 14). Antibody to DNA was sought by radioimmunoassay using native DNA labeled with ${ }^{3} \mathrm{H}$-actinomycin $\mathrm{D}(3)$. Control sera for this procedure were obtained from 20 normal adult staff members of the Canadian Red Cross Memorial Hospital, Taplow, England. Sera from 21 children with juvenile rheumatoid arthritis, 11 with dermatomyositis, and 25 with systemic lupus erythematosus were also studied by radioimmunoassay.

Statistical methods for evaluation of the results utilized the Student $t$ distribution, rank test, and median test derived from standard texts $(5,21)$.

\section{RESULTS}

Results of measurement of immunoglobulins and the third component of complement are shown in Table 1. IgG, IgM, and $\operatorname{IgA}$ are significantly increased in children with FS and PSS when the means are compared by the $t$ test. Application of the 
Table 1.Immunoglobulins (Ig) and $C^{\prime} 3$ in children with scleroderma and control subjects ${ }^{1}$

\begin{tabular}{|c|c|c|c|c|c|}
\hline & No. patients & $\mathrm{IgG}$ & $\operatorname{IgM}$ & $\operatorname{Ig} \mathrm{A}$ & $C^{\prime} 3$ \\
\hline FS & 17 & $\begin{array}{c}1620 \pm 976 \\
P<0.01\end{array}$ & $\begin{array}{c}169 \pm 162 \\
P<0.01\end{array}$ & $\begin{array}{l}180 \pm 64 \\
P<0.05\end{array}$ & $268 \pm 51$ \\
\hline Control subjects & 23 & $906 \pm 259$ & $57 \pm 68$ & $141 \pm 68$ & $240 \pm 96$ \\
\hline PSS & 6 & $\begin{array}{c}2142 \pm 1508 \\
P<0.01\end{array}$ & $\begin{array}{c}136 \pm 68 \\
P<0.01\end{array}$ & $\begin{array}{l}298 \pm 261 \\
P<0.05\end{array}$ & $288 \pm 71$ \\
\hline
\end{tabular}

${ }^{1} \mathrm{FS}$ : focal scleroderma; PSS: progressive systemic scleroderma.

Table 2. Antinuclear antibodies in children with scleroderma

\begin{tabular}{lccccc}
\hline & \multicolumn{5}{c}{ Substrate, $\%$} \\
\cline { 2 - 5 } \multicolumn{1}{c}{ Diagnosis } & $\begin{array}{c}\text { Human } \\
\text { WBC }\end{array}$ & $\begin{array}{c}\text { Rat } \\
\text { liver }\end{array}$ & $\begin{array}{c}\text { Nucleo- } \\
\text { histone }\end{array}$ & DNA & $\begin{array}{c}\text { No. } \\
\text { patients }\end{array}$ \\
\hline FS & 39 & $41^{2}$ & 55 & $31^{3}$ & 23 \\
PSS & 16 & $80^{4}$ & 0 & 0 & 6 \\
Dermatomyositis & 0 & 17 & 0 & 0 & 24 \\
Control subjects & 0 & 0 & 0 & 0 & 23 \\
\hline
\end{tabular}

${ }^{1}$ WBC: white blood cells; FS: focal scleroderma; PSS: progressive systemic scleroderma.

${ }^{2}$ Nine of 22 tested.

${ }^{3}$ Five of 16 (by radioimmunoassay).

${ }^{4}$ Four of five.

median and rank sum tests in the analysis of these data confirm the highly significant difference $(P<0.001$ for FS and 0.05 for PSS) between the control and scleroderma groups with respect to IgG and IgM levels. There was no significant difference between FS and PSS. The serum complement levels did not differ significantly. The IgG and $\operatorname{IgM}$ levels observed in the 7 children reported previously to have anti- $\gamma$-globulins (11) were significantly higher than those of the 16 children who did not have rheumatoid factor when compared by the rank test $(P<0.01)$

Antinuclear antibodies were demonstrated by one or more techniques in $13(57 \%)$ of 23 children with FS and in 5 of 6 children with PSS (Table 2). The control sera were negative for ANA. Antinuclear antibodies were clearly associated with high levels of $\operatorname{IgG}$ and $\operatorname{IgM}(P<0.01$ for both $)$. Patterns of immunofluorescent staining differed among the different clinical groups studied. The homogenous pattern prevailed in all patients with focal scleroderma with evidence of the speckled pattern also in five of the nine positive. Among those with PSS, two patients showed pure nucleolar staining in high titers and two the speckled pattern only. The homogenous pattern was not observed in the PSS sera. The speckled pattern only was observed in the dermatomyositis sera. The results of study of antibody to nucleohistone were consistent with these patterns, as antibody to nucleohistone was found in children with focal scleroderma and not in those with PSS. ANA were found with equal frequency in $\operatorname{IgG}$ and IgM classes, but in only one patient with FS in the IgA class.

Titer of antinuclear antibody ranged from undiluted to 1:256 in FS with human leucocytes as substrate and from 1:8 to $1: 512$ on nucleohistone spots in FS, and from $1: 10$ to greater than 1:1,000 with rat liver sections in FS and PSS

Values for DNA binding exceeding the mean plus 2 SD of the 20 normal adults were observed in 5 children with FS (Table 3). These values were $32.9 \%, 25.4 \%, 15.0 \%, 13.0 \%$, and $12.6 \%$. The mean binding of $9.43 \%$ for the FS group significantly exceeded $(P<0.05)$, the mean binding percentages of all of the other groups except systemic lupus erythematosus.
Table 3. Antibody to native DNA by radioimmunoassay ${ }^{1}$

\begin{tabular}{lccc}
\hline & $\begin{array}{c}\text { No } \\
\text { patients }\end{array}$ & $\begin{array}{c}\text { Mean binding, } \\
\%\end{array}$ & $\begin{array}{c}\text { No. }>10 \% \\
\text { binding }\end{array}$ \\
\hline FS & 16 & $9.43 \pm 8.79$ & 5 \\
PSS & 5 & $1.38 \pm 2.73$ & 0 \\
Normal adults & 20 & $5.07 \pm 2.22$ & 0 \\
Dermatomyositis & 11 & $3.92 \pm 3.24$ & 0 \\
JRA & 21 & $3.64 \pm 3.46$ & 1 \\
SLE & 25 & $20.93 \pm 18.02$ & 12 \\
\hline
\end{tabular}

${ }^{1} \mathrm{FS}$ : focal scleroderma; PSS: progressive systemic scleroderma; JRA: juvenile rheumatoid arthritis; SLE: systemic lupus ery thematosus.

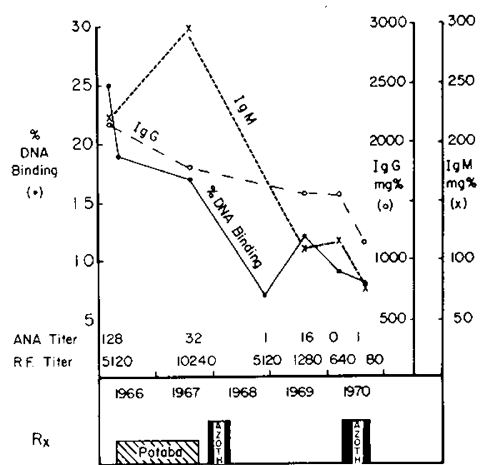

Fig. 1. Patient KR: correlation of serologic factors. The decline of these factors was accompanied by a reduction in disease activity. Potaba: potassium $p$-aminobenzoate, $1 \mathrm{~g}, 4$ times $/ 24 \mathrm{hr}$ : AZOTH: azothioprine, $75 \mathrm{mg} / 24 \mathrm{hr}$. ANA: antinuclear antibodies; R.F.: rheumatoid factor; $I g$ : immunoglobulin.

The persistence of antibody to DNA, other autoantibodies, and high levels of immunoglobulin in two patients with FS is shown in Figures 1 and 2 and the close correlation between changes in DNA binding and levels of $\operatorname{IgG}$ and $\mathrm{IgM}$ is noteworthy.

\section{DISCUSSION}

The data presented here are evidence of a significant stimulus to the immune system in both focal and systemic scleroderma. The possibility that the high levels of immunoglobulin might result from decreased metabolism has not been tested, but the frequent occurrence of anti- $\gamma$-globulins and antinuclear antibodies in high titers requires an active immunizing process and casts doubt that any purely passive process could account for the findings.

The 57\% incidence of ANA in FS is higher than that reported for juveniles with rheumatic disease other than systemic lupus erythematosus, (16). Oka and Ruotsi (19) reported ANA, elevated $\gamma$-globulins, and rheumatoid factor in a 14-year-old male with linear scleroderma, and Hickman and Sheils (13) reported similar findings in an adult male with 


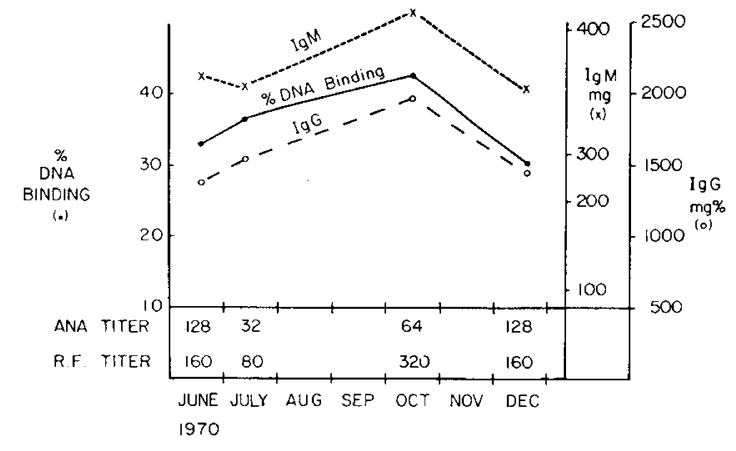

Fig. 2. Patient Ki.R.: percentage of DNA binding and serum immunoglobulin $(I g) \mathrm{G}$ and $\mathrm{M}$ over a 7 -month period. Coincident antinuclear antibodies $(A N A)$ and rheumatoid factor (R.F.) are shown along the ordinate.

facial hemiatrophy. Burge et al. (2) reported high levels of immunoglobulins in two sisters who had linear scleroderma but did not find antinuclear antibody or rheumatoid factor in either child.

Antibody to DNA determined by radioimmunoassay was found in FS but not in PSS. The close correlation between DNA binding and high levels of immunoglobulins in two patients suggested a dependent relation, but without further studies it is premature to conclude that DNA antigen is a stimulus to the production of large amounts of immunoglobulins. ANA, anti-DNA, and anti- $\gamma$-globulins were al associated with high levels of immunoglobulins and it is possible that these antibodies appear as a result of prolonged or intense stimulation of antibody production.

The absence of DNA binding antibody in six patients with PSS is consistent with previous studies by other techniques $(10,22)$, and suggests that the incidence of DNA binding antibody will prove to be lower in PSS than in FS when additional studies are reported. The possible role of DNA antibody complexes in the pathogenesis of FS is unexplored at this time.

The data presented in this paper do not in themselves substantiate a pathogenic role for serologic immune factors. Recently, McGiven et al. (18) found evidence of antibody and complement deposition in the kidneys of two patients with PSS but Fisher and Rodnan (6) found no evidence of $\gamma$-globulin localization in scleroderma skin or subcutaneous tissue.

Hayes and Rodnan (12) and Leroy (17) reported that collagen synthesis is increased in scleroderma skin and Fleischmajer and Prunieras (8) demonstrated an association of inflammation and deposition of collagen fibers in generalized morphea. Rodnan and Medsger (20) described the inflammation of skin, muscle, and synovium in progressive systemic sclerosis and showed that the peak of inflammation precedes the peak of fibrosis. Currie et al. (4) demonstrated that the peripheral blood lymphocytes in adult patients with PSS were cytotoxic to cultures of human fibroblasts and skin, muscle, and renal cells, whereas those from normal persons were not, which suggested that cellular as well as humoral immunity is altered. In a preceding study (15) the authors found evidence of inflammation in the skin or other organs in all cases of systemic or focal scleroderma with inflammatory infiltrates persisting as long as 10 years in one patient. These infiltrates were composed predominantly of lymphocytes or lymphocytes with macrophages, evidence in themselves of immune activity. The lesions in the skin and muscle of these patients did not distinguish between FS and PSS, as has also been reported by Fleischmajer et al. $(7,8)$.

In an overview, FS and PSS differ from one another in the grossly visible characteristics of skin involvement and in the involvement of intestinal tract, heart, lungs, or kidney in PSS.
Muscle and joint involvement are common to both. Histologic changes in affected tissue are indistinguishable. Immunologically, FS and PSS are similar in the presence of high levels of immunoglobulins, anti- $\gamma$-globulins, and antinuclear antibodies, but dissimilar in the absence or rarity of antibody to DNA and possible DNA-histone complex in PSS.

A case study is appended to this paper which illustrates the possible association of a DNA virus infection with the development of diffuse focal scleroderma. An hypotheses for future study is that the difference between the circumscribed nature of FS and the diffuse nature of PSS may be related to a deficiency of a specific antibody which could limit the spread of an exogenous antigen such as infective viral DNA.

\section{CASE STUDY}

The patient BRG (born August 21, 1970, CH no. 465899) first developed evidence of focal scleroderma in April 1972 with increased pigmentation of the skin on both cheeks and in patches over the right shoulder and right arm, with thickening of the skin in areas of hyperpigmentation. Marked axillary and inguinal lymphadenopathy were noted. Biopsy of the hyperpigmented area on the right shoulder in April 1972 showed focal aggregates of chronic inflammatory cells in the lower portions of the dermis. Six months previously at 1 year of age the patient developed a papular rash over the abdomen and enlarged anterior and posterior cervical lymph nodes with a slightly enlarged liver. Laboratory studies in November 1971 revealed: leucocyte count 15,100 , segs $15 \%$, bands $2 \%$, eosinophils $7 \%$, monos $2 \%$, lymphocytes $79 \%$ with many atypical forms. Mono spot test was positive. During the 6 months between the onset of apparent infectious mononucleosis and scleroderma-like skin lesions the patient had continued malaise and failed to gain weight. The skin lesions increased in number and extent of areas involved during the spring of 1972. Thrombocytopenia with platelet counts between 22,000 and 71,000 were noted during this period. In May 1972 the leucocyte count was 10,900 with segs $32 \%$, eosinophils $13 \%$, basophils $1 \%$, lymphs $51 \%$. VDRL was negative on two occasions and hemaglobin electrophoresis showed SA hemoglobin. Hilar adenopathy was noted on x-ray. Axillary lymph node biopsy in July 1972 showed only reactive hyperplasia. Esophagram and upper gastrointestinal series were normal. Repeat skin biopsy in July 1972 showed hypertrophic, closely spaced hyalinized collagen bundles with reduced fibroblasts and entrapment of the dermal appendages in collagen bundles. Small blood vessels showed thickening of the walls and a moderate chronic inflammatory cell infiltrate was identified at the cutaneous, subcutaneous border. Dr. Werner Henle reported Epstein-Barr virus titers consistent with active infection in September 1972 (Table 4). These titers subsequently decreased only to rise again in April 1973 with an apparent new increase in the extent of the skin lesions: Serum immunoglobulins in August 1972 were $\operatorname{IgG}, 1,670$

Table 4. Patient BRG: Epstein-Barr virus (EBV) titers ${ }^{1}$

\begin{tabular}{rccc} 
Serum date & Anti-VCA & Anti-EA & Type $^{4}$ \\
\hline $9 / 27 / 72$ & 160 & 40 & $\mathrm{D}$ \\
$12 / 20 / 72$ & 80 & 10 & \\
$4 / 18 / 73$ & 320 & 40 & $\mathrm{D}$ \\
$5 / 10 / 73$ & 320 & 10 & $\mathrm{D}$ \\
$10 / 24 / 73$ & 640 & 40 & $\mathrm{D}$ \\
\hline
\end{tabular}

${ }^{1}$ Titers performed by Dr. Werner Henle, University of Pennsylvania, School of Medicine and The Children's Hospital of Philadelphia.

${ }^{2} \mathrm{~EB}$ viral capsid antigens.

${ }^{3} \mathrm{EBV}$-induced early antigens.

${ }^{4}$ Anti-D observed during acute infections; anti- $R$ in chronic infections. 
$\mathrm{mg} / 100 \mathrm{ml} ; \mathrm{IgM}, 120 \mathrm{mg} / 100 \mathrm{ml}$; IgA, $170 \mathrm{mg} / 100 \mathrm{ml} ; \mathrm{IgE}, 52$ $\mathrm{mg} / 100 \mathrm{ml}$. Antinuclear antibody and latex fixation tests were negative but radioimmunoassay for DNA binding indicated $10.6 \%$ DNA binding, which was just above the upper limits of normal for that study. Progression of the skin lesions continued slowly with patchy depigmentation and increasing local fobrosis.

\section{REFERENCES AND NOTES}

1. Allansmith, M., McClellan, B. H., Butterworth, M., and Maloney, J. R.: The development of immunoglobulin levels in man. Pediat., 72: 276 (1968).

2. Burge, K. M., Perry, H. O., and Stickler, G. B.: "Familial" scleroderma. Arch. Dermatol., 99: 681 (1969)

3. Carr, R. I., Koffler, D., Agnello, V., and Kunkel, H. G.: Studies on DNA antibodies using DNA labelled with actinomycin-D $\left({ }^{3} \mathrm{H}\right)$ or dimethyl $\left({ }^{3} \mathrm{H}\right)$ sulfate. Clin. Exp. Immunol., 4: 527 (1969).

4. Currie, S., Saunders, M., and Knowles, M.: Immunologic aspects of systemic sclerosis: In vitro activity of lymphocytes from patients with the disorder. Brit. J. Dermatol., 84: 400 (1970).

5. Dixon, W. J., and Massey, F. J., Jr.: Introduction to Statistical Analysis, Ed. 2 (McGraw-Hill Book Company, Inc., Boston, 1957).

6. Fisher, E. R., and Rodnan, G. P.: Pathologic observations concerning the cutaneous lesion of progressive systemic sclerosis: An electron microscopic, histochemical and immunohistochemical study. Arthritis Rheum., 3: 536 (1960).

7. Fleischmajer, R., Damiano, V., and Nedwich, A.: Alteration of subcutaneous tissue in systemic scleroderma. Arch. Dermatol. 105: 59 (1972).

8. Fleischmajer, R., and Prunieras, M.: Generalized morphea. II. Electron microscopy of collagen, cells, and the subcutaneous tissue. Arch. Dermatol., 106: 515 (1972).

9. Friou, G.: Fluorescent spot test for antinuclear antibodies. Arthritis Rheum., 4: 407 (1962)

10. Hanson, V., Drexler, E., and Kornreich, H.: DNA antibodies in childhood scleroderma. Arthritis Rheum., 13: 798 (1970).

11. Hanson, V., Drexler, E., and Kornreich, H.: Rheumatoid factor

Copyright (c) 1974 International Pediatric Research Foundation, Inc. (antigammaglobulins) in children with focal scleroderma. Submitted for publication.

12. Hayes, R. L., and Rodnan, G. P.: The ultrastructure of skin in progressive systemic sclerosis (scleroderma). I. Dermal collagen fibers. Amer. J. Pathol., 63: 433 (1971).

13. Hickman, J. W., and Sheils, W.: Progressive facial hemiatrophy Arch. Intern. Med., 113: 716 (1964).

14. Holborow, E. J., and Johnson, G. D.: Immunoflourescence. In: D. M. Weir: Handbook of Experimental Immunology (Blackwell Scientific Publications, Oxford, 1967).

15. Kass, H., Hanson, V., and Patrick, J.: Scleroderma in childhood. J. Pediat. 68: 243 (1966).

16. Kass, H. K., Drexler, E., and Hanson, V.: Antinuclear factors in childhood rheumatic diseases. J. Pediat., 69: 1039 (1966).

17. Leroy, E. C.: Connective tissue systhesis by scleroderma skin fibroblasts in cell culture. J. Exp. Med., 135: 1351 (1972).

18. McGiven, A. R., deBoer, W. G. R. M., and Barnett, A. J.: Renal immune deposits in scleroderma. Pathology, 3: 145 (1971).

19. Oka, M, and Ruotsi, A.: Positive immuno-reactions in a case of unilateral scleroderma and progressive hemiatrophy. Acta Rheumatol. Scand., 15: 29 (1969).

20. Rodnan, G. P., and Medsger, T. A., Jr.: Musculoskeletal involvement in progressive systemic sclerosis (scleroderma). Bull. Rheum. Dis., 17: 419 (1966).

21. Schor, S.: Fundamentals of Biostatistics (G. P. Putnam's Sons, New York, 1968).

22. Seligman, M., Cannat, A., and Hamard, M.: Studies on antinuclear antibodies. Ann. N. Y. Acad. Sci., 124: 816 (1965).

23. Winkelman, R. K.: Classification and pathogenesis of scleroderma. Mayo Clin. Proc., 46: 83 (1971).

24. The present address of Lieutenant Commander G. A. MacPherson is: Rees-Stealy Medical Clinic, San Diego, Calif.

25. This paper was presented in part at the Society for Pediatric Research, May 1972, and XIII International Congress of Rheumatology, October 1973.

26. This study was supported in part by a grant from the Southern California Chapter of The Arthritis Foundation.

27. Requests for reprints should be addressed to: V. Hanson, M.D. Childrens Hospital of Los Angeles, P.O. Box 54700, Los Angeles, Calif. 90054 (USA)

28. Accepted for publication May 6, 1974.

Pediat. Res. 8: 809-814 (1974)

5-Hydroxyindolylacetic acid norepinephrine phenylketonuria

Printed in U.S.A.

\title{
Thermoregulation of Phenylketonuric Children
}

\author{
CLARK M. BLATTEIS, ${ }^{(36)}$ GERARD J. BILLMEIER, JR., AND THOMAS M. GILBERT \\ Department of Physiology and Biophysics and Child Development Center, The University of \\ Tennessee Medical Units, Memphis, Tennessee, USA
}

\section{Extract}

Children with untreated phenylketonuria exhibited abnormalities in their thermoregulatory defenses against heat and cold. At $37^{\circ}$, they sweated minimally, but displayed normal cutaneous vasodilatation. At $8^{\circ}$, they shivered and vasoconstricted normally, yet failed to maintain core temperature. 3-Methoxy, 4-hydroxy-D-mandelic acid (vanmandelic acid, VMA) excretion (at $26^{\circ}$ ) was more depressed than that of 5-hydroxy-3-indolylacetic acid (5-HIAA) in these subjects. The apparent imbalance between these amines could account, according to the monoamine hypothesis of temperature regulation, for their deficient sweating in $37^{\circ}$, thereby implicating norepinephrine as a possible central transmitter in the sudomotor response of man to heat. On the other hand, the inadequate heat conservation observed at $8^{\circ}$ probably was caused by unfavorable physical characteristics, e.g., higher surface area to weight ratio, or smaller subcutaneous insulation.

\section{Speculation}

The present findings suggest a possible involvement of norepinephrine and serotonin in the hypothalamic control of body temperature in man, in that the balance between these 